just as we can illuminate that work in turn. Get out your crosscut saws and saw away!

\section{Notes}

*The author wishes to acknowledge the helpful comments and support of Scott Barclay, Stephen Frantzich, and Michael Malbin.

1. Cigler (1997) has noted a similar phenomenon in the study of interest groups: Most interest group scholars tend to come from either a tradition of seeing political parties and interest groups as mediating entities or from voting behavior research (leading to an interest in PACs). They thus pay relatively little attention to interest groups in courts, and leave such activities out of the larger picture. Public law scholars, on the other hand, conduct most research on interest groups in court, but without adequate use of the broader interest group literature.

2. An example: Does it matter that U.S. district judges can seek elevation to the U.S Court of Appeals without leaving the district court, while members of the U.S. House of Representatives must give up their office to seek a Senate seat?

3. See Romzek and Utter (1996) for another study highly useful in prompting thoughts of the differences between legislative and judicial staff.

4. While those conducting social science research on the law have access to several such journals, particularly Law and Society Review and Law and Social Inquiry, comparable journals may not be as readily available in other subfields.

\section{References}

Barclay, Scott W., and Thomas A. Birkland. 1997. "Law, Policy Making, and the Policy
Process: Closing the Gaps." Presented at the annual meeting of the Midwest Political Science Association, Chicago.

Baum, Lawrence. 1983. "Judicial Politics: Still a Distinctive Field." In Political Science: The State of the Discipline, ed. Ada Finifter. Washington, DC: American Political Science Association.

- 1997. Comments. Panel on "Judicial Policy and the Problem of Implementation." Presented at the annual meeting of the Midwest Political Science Association, Chicago.

Baumgartner, Frank, and Bryan D. Jones. 1993. Agendas and Instability in American Politics. Chicago: University of Chicago Press.

Bierman, Luke. 1994. "Institutional Identity and the Limits of Institutional Reform: The New York Court of Appeals in the Judicial Process." Ph.D. diss. University at Albany-SUNY.

Cigler, Allen. 1997. Comments. Panel on "Organized Interests, Avenues of Influence and the Judiciary." Presented at the annual meeting of the Midwest Political Science Association, Chicago.

Cook, Timothy E. 1989. Making Laws \& Making News: Media Strategies in the U.S. House of Representatives. Washington, DC: The Brookings Institution.

Grumm, John G., and Stephen L. Wasby, eds. 1981. The Analysis of Policy Impact. Lexington, MA: Lexington Books.

Johnson, Charles A., and Bradley C. Canon. 1984. Judicial Policies: Implementation and Impact. Washington, DC: Congressional Quarterly.

Kingdon, John W. 1995. Agendas, Alternatives, and Public Policies. 2nd ed. New York: Harper Collins.

Nakamura, Robert T., and Frank Smallwood. 1980. The Politics of Policy Implementation. New York: St. Martin's Press.

Romzek, Barbara S., and Jennifer A. Utter. 1996. "Career Dynamics of Congressional Legislative Staff: Preliminary Profile and Research Questions." Journal of Public Administration Research and Theory 6:415-42.
Schlesinger, Joseph A. 1966. Ambition and Politics: Political Careers in the United States. Chicago: Rand McNally.

Wasby, Stephen L. 1970. The Impact of the United States Supreme Court: Some Perspectives. Homewood, IL: Dorsey Press. . 1977. "Communication Within the Ninth Circuit Court of Appeals: The View from the Bench." Golden Gate University Law Review 8:1-25.

1987. "Communication in the Ninth Circuit: A Concern for Collegiality." University of Puget Sound Law Review 28:73138.

Whiteman, David. 1995. Communication in Congress: Members, Staff, and the Search for Information. Lawrence: University Press of Kansas.

Williams, Shirley, and Edward L. Lascher, Jr., eds. 1993. Ambition and Beyond: Career Paths of American Politicians. Berkeley: Institute of Governmental Studies.

\section{About the Author}

Stephen L. Wasby is professor of political science, SUNY, Albany. During

1997-1998, he is Bissell-Fulbright Chair in Canadian-American Relations at the University of Toronto.

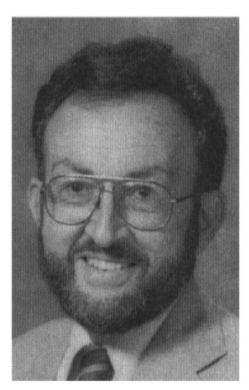

\title{
The Future of Our Discipline: The Status of Doctoral Students in Political Science
}

\author{
Julie Dolan, Shippensburg University \\ Martha E. Kropf and Karen O'Connor, American University \\ Marni Ezra, National Science Foundation
}

The future of our discipline rests in the hands of those individuals still pursuing their doctorates. The way we train our doctoral students to handle their roles as future professors will have a lasting impact on the discipline. When graduate students make the transition from student to professor they are supposed to have learned the skills they will need to be successful teachers and researchers. However, it is unclear whether graduate students in political science receive the training they need to immediately assume these roles. This article is intended to be a first step in a long-term scholarly inquiry into the status and training of graduate students preparing for careers in political science. In particular, we investigate the extent to which graduate students have already begun engaging in professional activities such as teaching, presenting at conferences, and submitting manuscripts to scholarly publications.

Specifically, we examine three re- 
lated areas of inquiry. First, we examine the nature and extent of teaching preparation graduate students receive from their institutions. Are graduate students getting any training before they enter the classroom, or are they being thrown to the wolves? Second, we explore graduate student participation at professional conferences. Are they encouraged to attend or provided travel funds by their institutions to make presenting their research at these conferences feasible? Finally, we inquire into the rate at which graduate students submit articles to scholarly journals and the rates at which graduate student submissions are accepted or rejected. We then use the results of our research to assess whether graduate students are being adequately prepared for academic careers that will require them to teach and do research.

\section{Methodology}

In 1989, Euchner and Jewell surveyed all $118 \mathrm{Ph}$.D.-granting political science programs in the U.S. to determine the types of teaching experiences afforded graduate students. Unlike Euchner and Jewell, who surveyed graduate programs directly, we opted to begin our analysis with an examination of graduate student perceptions and actual experiences. In May of 1996, we sent a survey entitled "The Status of Graduate Students" (see Appendix A) to 1000 graduate students whose names had been generated by the American Political Science Association (APSA) from a list of all its graduate student members (approximately 3,000 total). We pre-tested the survey on graduate students at American University and a select group of graduate students who attended the 1996 Midwest Political Science Association meeting. We administered the survey only once since we received an initial response rate of almost fifty percent (480 responses which yielded 423 usable surveys). Respondents were guaranteed that their individual responses would be kept confidential.

Our sample may overrepresent highly motivated graduate students since we used the APSA's member- ship rolls as the source of our mailing list. Nevertheless, we do not expect this fact to present any problems in our analysis. We might expect APSA student members to be more interested in research than a larger sample of graduate students in the United States if only because they have taken the step to subscribe to the discipline's leading journal. We expect that our findings will present the "best case" scenario concerning graduate student socialization into the profession.

Our sample accurately represents the population of political science graduate students in terms of race and gender. Sixty-one percent are male and thirty-nine percent female. The gender figures closely match those of the larger graduate student population; the APSA reports that 34 percent of all political science doctoral students are women (APSA 1996, 319). Our sample also adequately mirrors the racial composition of the discipline more generally: 82 percent of those surveyed were white, 4.7 percent African American, 4.3 percent Asian, 3.3 percent Latino, and 0.2 percent were Native American (see APSA 1996, 319).

Because some of the analysis below attempts to control for the quality of the political science programs of which respondents were members, we ranked $\mathrm{Ph}$.D.-granting departments according to the rankings reported in "Relative Rankings for Research-Doctorate Programs in Political Science" (NRC 1996, 14648). Though some controversy surrounds these rankings (see for example, Miller et al. 1996), they are the current standard in the discipline. In addition, we ranked political science journals according to "Political Scientists' Journal Evaluations Revisited," reported in the September 1989 issue of PS (Giles, Mizell, and Patterson 1989). This article ranks the top 78 political science journals according to their perceived quality.

\section{Findings $^{2}$}

\section{Teaching}

If the majority of students entering doctoral programs want to pur- sue some type of academic career, then it is crucial that they leave their graduate programs trained and socialized to handle their teaching responsibilities. In 1992, the Association of American Colleges (AAC) issued a report highlighting the frustration of deans, provosts, and university presidents "about the difficulties they experience in finding new Ph.D.s who are prepared to begin teaching" (AAC 1993, 255). They also note how difficult it is for many recent doctoral graduates to balance their new teaching and research responsibilities, especially at institutions where teaching, and not research, is "at the center of the faculty member's work" $(1993,255)$.

To determine whether doctoral candidates are likely to pursue careers that involve teaching responsibilities, we asked them to indicate their top job preferences. The vast majority of our sample desire jobs in the professoriate. Eighty-four percent expressed the desire to teach at a four-year college or university. Only 2.8 percent were interested in a government job, and only 1.9 percent expressed a desire to go into business upon graduation. Further, most respondents aspire to researchoriented careers; two-thirds of the sample prefer a position in a Ph.D.granting institution. Clearly large universities (those with more than 20 faculty members) are perceived as the most desirable places to work as half of those students who indicated they wanted a position in academia chose this type of institution (see Table 1).

The vast majority of graduate students desire positions in the academy. While teaching is more valued in some institutions than others, it is required to a certain extent of all new professors. Are graduate students being prepared for their future as teachers? To answer this question we asked students about two types of teaching preparation: participation in some type of teaching seminar and actual classroom teaching experience.

Teaching Preparation. Slightly more than half of the sample (55 percent) reported that their institution offers some type of teaching seminar. Among those students enrolled in 
TABLE 1 First Career Preferences Among Ph.D. Students

\begin{tabular}{lc}
\hline \multicolumn{1}{c}{ Type of Position } & $\begin{array}{c}\text { Percentage of } \\
\text { Students Listing }\end{array}$ \\
& $\begin{array}{c}\text { as First Preference } \\
\text { Ph.D.-Granting Institution With Greater than 20 Faculty }\end{array}$ \\
Ph.D.-Granting Institution With Fewer than 20 Faculty & 41.7 \\
MA-Granting Institution & 19.8 \\
BA-Granting Institution & 7.1 \\
Community College & 15.7 \\
Other Academic Position & 1.0 \\
Government & 1.9 \\
Business & 2.9 \\
Other Non-Academic Position & 1.9 \\
Not Sure & 2.6 \\
\hline
\end{tabular}

graduate programs that offer a teaching seminar, ${ }^{3}$ only 41 percent report that they are required to attend that seminar. This is similar to Euchner and Jewell's finding of 43 percent. Almost one in five students (18 percent) reported that they are required to teach as a condition of their fellowship, assistantship, or degree completion, but only 68 percent of the students required to teach reported having access to a teaching seminar of some type.

Further, the training available does not appear to be an ongoing and comprehensive part of most of students' programs. The majority of the students ( 88 percent) reported that their teaching seminars met for one semester or less, and 38 percent of respondents who have taught their own course did not have the opportunity to attend any type of teaching seminar before assuming their classroom responsibilities.

Teaching Experience. We also inquired about the first-hand teaching experience graduate students receive prior to graduation. Despite the agreed-upon need for some type of formal teaching training (Euchner and Jewell 1989; Henschen 1993), classroom experience will clearly help new Ph.D.s adjust to their new positions that almost always require some amount of teaching. Responthey had taught, when they began teaching, and what types of courses they had taught.

Less than half of the students in dents were asked to indicate whether our sample (44 percent) reported that they had taught a class on their own as graduate students. Focusing on those who have started teaching, the profile of a typical graduate student is someone who begins teaching at his or her own institution in the third year of graduate studies, who has taught an average of three courses, and is equally likely to teach introductory or upper level courses.

Interesting differences appear between those who have and have not taught. As revealed in Table 2, there are four factors that significantly influence whether or not students gain teaching experience before they depart from their doctoral programs. Students who were encouraged to teach were more likely to report that they had taught a course. This was an unsurprising finding. When faculty and institutions are supportive of graduate teaching, doctoral students will be more likely to teach a course before they graduate. In addition, encouraged students will teach significantly more courses than unencouraged (or discouraged) students.

Also closely associated with students' teaching experiences are the years students have spent in their respective programs and the types of institutions they attend. As expected, students more advanced in doctoral programs were more likely to have taught than students in the early years of their graduate studies. Only 16 percent of first-year students have taught their own classes, but more than two-thirds (69 percent) of fifthyear students have acquired such teaching experience. In addition, doctoral students at the least prestigious institutions are more likely to teach than students at the topranked schools. ${ }^{4}$ Finally, those at public schools are more likely to have teaching experience than individuals at private universities (48 percent and 35 percent, respectively) and to have taught significantly more

\section{TABLE 2}

\section{Factors Affecting Likelihood of Teaching Own Course*}

\begin{tabular}{lcc}
\hline & $\begin{array}{c}\text { \% Who Have } \\
\text { Taught }\end{array}$ & $\begin{array}{c}\text { Average \# } \\
\text { Classes Taught }\end{array}$ \\
\hline Encouraged to teach & 52.3 & 3.67 \\
Not encouraged to teach & 31.2 & 2.42 \\
Enrolled at. . . & 47.7 & 3.62 \\
Public University & 35.2 & 2.36 \\
Private University & & \\
& 41.5 & 2.72 \\
School Ranked in Top 1/3 & 39.6 & 3.26 \\
School Ranked in Middle 1/3 & 52.1 & 2.40 \\
School Ranked in Bottom 1/3 & 16.1 & 1.00 \\
Year in Program & 23.1 & 2.37 \\
1st year & 34.2 & 2.37 \\
2nd year & 52.2 & 2.31 \\
3rd year & 69.4 & 2.52 \\
4th year & & \\
5th year & &
\end{tabular}


classes. These results are both interesting and expected as public universities are known to utilize their graduate students more heavily than private universities to cover increasing undergraduate teaching demands.

We found that about half of the doctoral students in our sample acquired some type of teacher training, either in the form of a teaching skills seminar or by teaching their own classes. If an overwhelming majority of graduate students envision themselves pursuing a career in university teaching, it is surprising that more students are not receiving hands-on preparation for their prospective jobs.

\section{Conference Participation}

Attending conferences is also a part of becoming socialized into the political science profession. Presenting at conferences is crucial not only for receiving feedback about research, but for networking with established scholars. Thus, a second goal of our study was to determine whether students attend and participate in political science meetings. Examining the typical doctoral candidate, we find that not only has he attended a conference, he has also presented a paper. Eighty-seven percent of the graduate students sampled reported attending at least one professional association meeting, and 64 percent reported that they have given a conference paper.

We also investigated whether universities and faculty assist their students by facilitating presentations. Do they provide conference funding? Do professors encourage students to present? Do professors ask students to co-author articles with them? Furthermore, are these activities related to students' presentation rates?

First, departmental encouragement of student participation is positively related to conference participation. A vast majority of students, 80 percent, reported that they are encouraged to present their research at conferences. Those who are encouraged are significantly more likely to present a paper than those who are not. Second, beyond words

\section{TABLE 3 \\ Factors Affecting Conference Paper Presentation*}

\begin{tabular}{lc}
\hline \multicolumn{1}{c}{ Variable } & $\begin{array}{c}\text { Conference } \\
\text { Presentation }\end{array}$ \\
\hline $\begin{array}{l}\text { Encouraged to Present } \\
\text { Not Encouraged to }\end{array}$ & $69 \%$ \\
Present & $44 \%$ \\
Funding Provided & $68.9 \%$ \\
Funding Not Provided & $35.4 \%$ \\
Asked to Coauthor & $76.7 \%$ \\
Not Asked to Coauthor & $58.5 \%$ \\
Top $1 / 3$ School & $63.7 \%$ \\
Next $1 / 3$ & $63.7 \%$ \\
Final $1 / 3$ & $63.0 \%$ \\
\hline *With the exception of university \\
rank, all differences presented are \\
significant at a minimum of $p<.05$ \\
and are in the predicted direction.
\end{tabular}

of encouragement, the provision of funds to offset travel expenses is significantly related to research presentation. ${ }^{5}$ Eighty-four percent of students reported that their departments provide some form of conference funding. Finally, faculty members asking students to coauthor papers for conference presentation makes it significantly more likely that graduate students will have done so. Unfortunately, only 28 percent of the graduate students said that they had been invited to coauthor a conference paper by a faculty member at their university and only 30 percent of those who have presented have done so with a faculty member.

We expected that students from more prestigious universities would be more likely to have presented their research at scholarly conferences simply because such students have access to better resources. This expectation, however, was not borne out in our analysis. Students from more prestigious institutions are not significantly more likely to present their research than those from less prestigious universities. Thus, faculty and department involvement are clearly more important than the prestige of the institution when it comes to doctoral student conference presentation.

\section{Publications}

Another aspect of professional development is the submission of articles to professional journals. Publishing, or simply submitting an article, can provide students with feedback and help them understand the process of seeing a research project through to completion. However, even with the high value placed on publications in our discipline, a typical student has not submitted an article to a scholarly journal or even written a book chapter. Only 33 percent of doctoral students reported having submitted an article to a refereed journal. An additional 14 percent of our sample had written a chapter in an edited volume. Only one in five had submitted more than one article for review.

Of the doctoral students who had submitted articles for publication, the success rate (number of acceptances) was quite high-almost 50 percent reported that they had published an article or had one that was forthcoming. However, this figure does not give any indication of the quality of the journal in which the article appeared or would appear. When only publication in the top 78 journals in the profession was considered, only 16 percent of all student-submitted articles were pub-

\begin{tabular}{|c|c|}
\hline Variable & $\begin{array}{l}\text { Journal } \\
\text { Submission }\end{array}$ \\
\hline Asked to Coauthor & $47.1 \%$ \\
\hline Not Asked to Coauthor & $25.6 \%$ \\
\hline Conference Paper Given & $44.6 \%$ \\
\hline No Conference Paper & $11.8 \%$ \\
\hline Top 1/3 School & $35.8 \%$ \\
\hline Next $1 / 3$ & $30.8 \%$ \\
\hline Final $1 / 3$ & $27.7 \%$ \\
\hline
\end{tabular}


lished or forthcoming. Thus, only five percent of our entire sample, 22 graduate students, fall into the elite group of individuals who have published in the top professional journals. What factors lead students to take the critical first step toward publication, simply submitting their articles?

Our results indicate that faculty members can influence the rate at which students submit papers for publication. As a part of the socializing and mentoring that takes place in doctoral programs, some faculty members ask graduate students to coauthor articles for publication in a refereed journal. According to the results of our analysis, students who are asked to coauthor are significantly more likely to have submitted articles for publication. Though one might think that coauthoring with a faculty member is the rule, the unfortunate reality is that only onethird of our sample report that they have been asked to coauthor a paper for publication.

Not surprisingly, students who have presented a paper at a conference are significantly more likely to have submitted an article to a scholarly journal. Students farther along in their Ph.D. studies are much more likely to have submitted an article. Finally, as with conference attendance, the ranking of the institution the person attends has no relationship to submitting a paper.

\section{Conclusion}

Since an overwhelming majority of graduate students hope for an academic career, they must be prepared for what their future employment will hold. Depending on the institution in which they hopefully find a job, they will need to balance some aspects of both teaching and research. Therefore, it is essential that new professors be ready to hit the ground running. That is, they must have a research agenda and some experience teaching the courses they will be assigned in their first year. This paper is a first effort to start a dialogue within the profession concerning graduate teacher training and socialization into the profession. Are political science programs ade- quately preparing their graduate students to be productive future teachers and scholars?

We explored two forms of teacher training, teaching seminars and actual classroom experience, and found that only approximately half of our sample had participated in either activity. This finding can be viewed as both encouraging and troubling. It is beneficial for students to have the opportunity to teach their own classes during their graduate careers since they will then enter their new jobs more prepared to deal with their teaching responsibilities. However, many students (37.6 percent) who are allowed or required to teach courses said they did not receive any institutional training. Our data also reveal that teaching appears to be given generally low priority in many departments; more than half of the Ph.D. programs still do not provide formal training.

In the realm of conference participation, graduate students are preparing themselves to enter the discipline by attending and participating in acade ic conferences. Based on the over whelming percent of graduate students who participate in these meetings, it appears students understand the benefits of attendance.

Unlike academic conferences, where participation levels are high, only 33 percent of graduate students surveyed reported submitting their research for review at refereed journals. Since this avenue for publication is the most accessible to graduate students, it is surprising that more graduate students are not taking the opportunity to have their work reviewed by experts in their fields.

Our mo $t$ important finding, which bears repeating, is the importance of faculty involvement in students' socialization and training. When students report feeling that they are encouraged to engage in professional activities, the results are consistently positive; they are more likely to teach, present research, and submit articles for publication. The message should be clear. Institutional efforts to socialize students by encouraging them to present their research at conferences alone or in conjunction with a faculty member, particularly when backed up by institutional fi- nancial support, appears to be an easy and effective method of socializing students into the profession.

Appendix A: Variable Coding
Teaching Seminar-Whether
school offers teaching seminar
$1=$ yes, $0=$ no
Encouraged to Teach-
$1=$ yes, $0=$ no
Encouraged to Present-
$1=$ yes, $0=$ no
Asked to Co-author Conference
Paper-1 = yes, $0=$ no
Asked to Co-author Potential
Publication-1 = yes, $0=$ no
Funding Provided for
Conference- $1=$ yes, $0=$ no or
"not sure" or "don't know"
Institution-Ranking of the
institution based on the PS list.
More prestigious institutions given
lower numbers.
Public/Private- $1=$ private
university, $0=$ public university
Required to Teach-
$1=$ yes, $0=$ no
Year in Program-Number of
years in Ph.D. program at the time
of the survey

\section{Notes}

1. The authors would like to express our appreciation to Rob Hauck at the American Political Science Association for his assistance, and, in particular, his valuable comments and suggestions on our survey. We would also like to thank Michael Brintnell for his comments on an earlier version of this paper that was presented at the 1996 Annual Meeting of the Northeastern Political Science Association, Boston, Massachusetts.

2. All of the data in the following sections have also been run using multivariate models. Though the results presented here do not employ multivariate techniques, they support the results found in the OLS and logistic regressions. All multivariate analyses are available from the authors upon request.

3. This is the same percentage that Euchner and Jewell (1989) found seven years ago in their survey of political science departments. 
4. We divided the population of institutions into "high-," "medium-," and "low-quality" by simply partitioning the number of institutions in the $P S$ list into thirds. Such partitioning did not give us equal number of students in each category, however it was the most logical and simple way to divide the sample.

5. Or, more accurately, a department can publicize the fact that funding is available, because many students were "not sure" or "didn't know" about the availability of money for conference attendance, and were thus categorized as not receiving funding. We conclude that not knowing there is funding is as large a barrier as having none at all.

\section{References}

Association of American Colleges. 1993. "A Challenge to Graduate Education: Better Preparation for a New Generation of College Teachers-An Executive Summary."

PS: Political Science and Politics 26:255-57. American Political Science Association. 1996.
Survey of Political Science Departments. Washington, DC: APSA.

Euchner, Ethan P., and Malcolm E. Jewell. 1989. "A Survey of Teaching by Graduate Students." PS: Political Science and Politics 22:73-76.

Giles, Michael W., Francie Mizell, and David Patterson. 1989. "Political Scientists' Journal Evaluations Revisited." PS: Political Science and Politics 22:613-17.

Henschen, Beth. 1993. "Easing the Transition: From Doctoral Student to Academic Professional." PS: Political Science and Politics $26: 80-81$.

Mann, Sheilah. 1996. "Political Science Departments Report Declines in Enrollments and Majors in Recent Years." PS: Political Science and Politics 29:527-33.

Miller, Arthur H., Charles Tien, and Andrew A. Peebler. 1996. "Department Rankings: An Alternative Approach." PS: Political Science and Politics 29:704-17.

National Research Council. 1996. "Departmental Rankings: Much Ado About Something?" PS: Political Science and Politics 29:144-48.

\begin{abstract}
About the Authors
Marni Ezra is a contractor with the National Science Foundation. She was previously an assistant professor in the department of government and law at Lafayette College. She received her doctorate from American University in 1996.
\end{abstract}

Julie Dolan is a visting assistant professor of political science at Shippensburg University. She is also the 1997 recipient of the National Association of Schools of Public Affairs and Administration (NASPAA) Annual Dissertation Award for the best dissertation in public administration. Her current work focuses on the roles, responsibilities, and attitudes of elites in the federal bureaucracy.

Martha E. Kropf is a fifth-year doctoral candidate at American University. Her areas of research are political behavior/media politics and public policy. She is currently employed as a project coordinator at the University of Maryland Survey Research Center and she expects to complete her dissertation in December, 1997.

Karen O'Connor is professor and chair of the department of government at American University. She is the coauthor of Women, Politics, \& American Society, 2nd ed. (with Nancy E. McGlen, forthcoming) and American Politics: Continuity and Change (with Larry Sabato, 1997). 